\title{
Classification of Homonymic Terms in Medical Terminology of English, Russian and Tatar Languages
}

\author{
Venera Khisamova'
}

\author{
Liliia Abdullina ${ }^{2}$
}

\section{Leila Nurgalieva ${ }^{3}$}

\section{Elmira Khabibullina3}

\author{
'Professor, Doctor of Philological Sciences, \\ Institute of International Studies, Kazan Federal University, \\ ${ }^{2}$ Lecturer, Institute of International Studies, \\ Kazan Federal University, \\ ${ }^{3}$ Associate Professor, Candidate of Philological Sciences, \\ Institute of International Studies, Kazan Federal University
}

DOI: https://doi.org/10.36941/jesr-2020-0107

\begin{abstract}
This study is undertaken to identify the similarities and differences of classification of homonyms in medical terminology of English, Russian and Tatar languages. In this paper a comparative method was used to identify the common and special in the compared languages. The basis of comparison in the medical terminology of genetically unrelated languages was established. In this study, the method of feature comparison was used, i.e. the phenomenon of homonymy was studied in a comparative aspect. The results of this study contribute to ordering the terms, the selection of the correct, appropriate term when translating medical texts from one language into another. The languages under the consideration have intra-terminological, inter-terminological, inter-system homonymy. Besides, there are homonymic relations between eponyms in all languages. In the medical terminology of the English language, the following groups of homonyms are found: absolute, incomplete, partial (homophones, homographs) homonyms. Incomplete homonyms are divided into lexical and lexical and grammatical, and partial homonyms are divided into lexical, lexical and grammatical, grammatical (homonymsconverse terms). Homophones, in turn, are classified into homophones and near homophones. Homonyms are classified into homonyms of a high degree of homonymity, homonyms of a medium degree of homonymity, homonyms of a low degree of homonymity in Russian medical terminology. In medical terminology of the Tatar language absolute and incomplete homonyms are distinguished. Incomplete homonyms include homoforms that belong to different parts of speech and homographs. Homographs are rare phenomenon in the medical terminology of the Tatar language. Separately, as a special group, homonyms-converse terms are considered. There are three types of functional shift relations in the Tatar language: syntactic, lexical and semantic, the most common of which is syntactic relation. The phenomenon of homonymy affects the Greek-Latin terminological elements, which are international. Comparative analysis of three languages in the matter of homonyms in medical terminology has shown that English and Tatar languages have more similarities than English and Russian ones and Russian and Tatar ones. The English medical terminology is more replete with homonymous acronyms than Russian and Tatar ones.
\end{abstract}

Keywords: classification, homonymy, medical terminology, the English language, the Russian language, the Tatar language 


\section{Introduction}

The study of medical terminology is one of the promising directions in modern science, since the vocabulary of languages, including national ones, is developed with the new terms.

Problems of classification of homonymic terms, i.e. terms that have several - not bound meanings is one of the important problems of terminology up to the present day.

The term is not a special word, but a word in a special function, and the same lexical-semantic phenomena, including homonymy, are natural for a term as for a word from a common language. In addition, the classification of homonymous terms in medical terminology of genetically unrelated languages, namely, English, Russian and Tatar languages in a comparative aspect has not been studied yet.

The study of homonymy in the medical terminology of multi-structural languages will help determine the general qualities and specific features of the phenomenon of homonymy, which will help to arrange the terms and take into account the features of the phenomenon of homonymy in these languages when translating the medical texts from one language to another, since homonymous terms of one language can be non-homonymous in another.

This study is devoted to the study of problems of classification groups of homonymous terms in medical terminology of English, Russian and Tatar languages in particular. English is an international language of science; Russian is the national language of the Russian people and is one of the most widely spoken languages in the world - the sixth among all languages of the world in terms of the total number of speakers and the eighth in terms of those who speak it as a native; and the Tatar language is the second most widespread and most spoken national language in the Russian Federation.

\section{Theoretical Background}

Classification in terminology is a very important aspect, since through the classification scheme the logical-conceptual structure of the subject area in all forms of its connections and relationships is revealed and demonstrated. It occupies an important place in any science. Classification of objects of interest is a traditional method of cognition. Classification arises at a certain stage in the development of sciences, when it becomes necessary to evaluate and reevaluate data for study, to identify a hierarchy of scientific concepts and the relationship of research objects (Averbukh, 2005: 208).

N.I. Kondakov (1976: 247) defines the classification as follows: "the distribution of objects of any kind into interrelated classes according to the most essential features present in objects of this kind and distinguishing them from objects of other kinds, with each class occupying a certain fixed place in the resulting system and, in turn, divided into subclasses"

K.Ya. Averbukh (2005: 209-210) emphasizes that classification is only one type of operation, called the division of concepts, which essentially reduces to dividing the scope of concept into subclasses, which are types of objects conceivable in this concept. The sign, by which division of the scope of concept is made, is called the characteristic of division. Division occurs on one specific characteristic. K.Ya. Averbukh also distinguishes three main points in the division: 1 . The scope of the concept to be divided must be equal to the sum of the scopes of the members of the division; 2 . The members of the division must mutually exclude each other, i.e. not have common elements; 3 . The division must be continuous, i.e. it is necessary to take the nearest subclass and not jump to a farther one.

V.M. Leichik, S.D. Shelov (1990: 22-35) noted that there are various classifications in which the terms are grouped according to different characteristics: content, language form, function, intralinguistic and extra-linguistic features. The classification is based on typology. Typology is the division of the whole set of terms into groupings, types according to these criteria. Typology, as a result of the allocation of types, defines objects by their entities. Classifications with a greater or lesser degree of artificiality divide the area under consideration by reference to certain characteristics. Therefore, in a typology, the terms should be distributed according to some essential features that are present in the terms regardless of the particular term system and which are manifested in the maximum number of 
particular features of the terms. Such an essential feature of terms is designation with them of general, special concepts: that way the terms are contrasted with other nominative classes of vocabulary, which are intended to designate particular and individual concepts. The types of terms depend on the types of general concepts. First of all, the most general concepts of matter and its attributes are distinguished, which got the name of the categories in philosophy and logic: e.g., eng. matter, rus. materiya tat. materiya; eng. space, rus. prostranstvo, tat. prostranstvo; eng. time, rus. vremya, tat. vaqit; eng. quantity, rus. kolichestvo, tat. miqdar; eng. quality, rus. kachestvo, tat. slyfat; eng. measure, rus. mera, tat. ülçäü berämlege etc. Further, at each stage of the development of human knowledge, in each era, a certain number of general scientific (as well as general technical) concepts, that are used in any science, industry in the definitions of their specific concepts, are named: e.g., eng. system, rus. sistema, tat. sistema, eng. method, rus. metod, tat. metod, eng. law, rus. zakon, tat. zakon etc. in science; eng. production, rus. proizvodstvo, tat. citeșterü; eng. semi-finished product, rus. polufabrikat, tat. yarımfabrikat; eng. reliability, rus. nadezhnost', tat. ışanıçllıq etc. in technics. Inter-sectorial concepts, which are used not in all, but in many areas of knowledge, adjoin them, e.g., eng. information, rus. informatsiya, tat. informatsiya; eng. management, rus. upravlenie, tat. idarä; eng. modeling, rus. modelirovanie, tat. modelirovanie; eng. element, rus. element, tat. element etc. There are specific concepts of varying degrees of generalization in each field of knowledge and activity - from the largest classes (genera) to the smallest species lying on the lower levels of the hierarchy, as well as concepts that reflect aspects of the consideration of these classes (hierarchical subordinate relation). These two types of concepts are called specific and aspectual. For example, in medicine, eng. acute pneumonia, rus. ostraya pnevmoniya, tat. ütä köçle pnevmoniya is a specific concept regarding the concept of eng. pneumonia, rus. pnevmoniya, tat. pnevmoniya etc. The types of concepts listed above find their linguistic realization in the types of terms. The terms of categories, general scientific and general technical terms, inter-sectorial, niche terms are distinguished.

According to V.M. Leichik, S.D. Shelov (1990: 22-35), the difference between the typology and classification of the term is that the typology divides the terms according to the main, essential feature, and numerous classifications of terms group them according to various particular characteristics. Since the term is a multi-aspectual phenomenon, these aspects are used as the characteristic for the division of sets of terms in their classification processing.

The main classification of terms is their distribution according to the object of nomination, termination. This classification includes all special fields of knowledge and activities of modern society. First, a class of scientific terms is distinguished, after it falls into as many subclasses as there are sciences at a certain stage of scientific and technological progress. In each subclass of terms, there are as many groups as there are various independent theories for describing objects and patterns. The terms of natural, which includes medicine, social and technical sciences, are distinguished. General scientific and inter-sectorial terms refer to several groupings simultaneously.

Medical terminology is very diverse and complex and can be classified by various characteristics into different types. First of all, some types, distinguished by V.M. Leichik and S.D. Shelov (1990: 2235) for terminological systems in general - which are also found in medical terminology - are considered. The authors identify several classes of terms, presenting the characteristic of division: logical, linguistic, statistical, normative, historical classifications etc.

1. Substantive classification of terms is classification by the logical category of the concept that is denoted by the term. The terms of objects, e.g., eng. kidney, erythrocyte; rus. zheludok 'stomach', opukhol' 'tumor'; tat. üpkä 'lung', biz 'gland' etc .; processes, e.g., eng. deworming, bleeding; rus. vospalenie 'inflammation', intoksikatsiya 'intoxication'; tat. tarkalu 'catabolism', reabilitatsiya 'rehabilitation' etc.; signs, e.g., eng., cyanosis, cystic; rus. blednost' 'pallescence', tabletirovanniy 'tableted'; tat. quzıllıq 'rubeosis', allergik 'allergic' etc.; quantities and their units, e.g. eng. mass, rus. massa, tat. massa, eng. kilogram, rus. kilogram, tat. kilogram etc. are distinguished

2. Linguistic classification includes several characteristics of division:

A. according to the formal structure (terms-words, terms-phrases, terms-abbreviations, 
terms-symbol-words etc., e.g., eng. necrosis, hemorrhagic fever, CNS, B cell; rus. ishemiya 'ischemia', mochevoy puzir' 'bladder', VPCH 'HPV', $\alpha$-globulin ' $\alpha$-globulin'; tat. daru 'drug', kendek kısılu 'occlusion of umbilical cord', $\mathrm{AB}$ 'BP', ß-terapiya 'ß-therapy' etc.);

B. according to the content-related structure (monosemantic terms, multivalent terms, terms-free phrases, terms-standard collocation, e.g., eng. mastitis, nutrition, neurogenic bladder, hilar dance; rus. glomerulonefrit 'glomerulonephritis', pristup 'paroxysm', 'attack', 'exacerbation', gemoliticheskaya anemiya 'hemolytic anemia', plyaska Svyatogo Vita 'St. Vitus dance'; tat disfagia 'dysphagia', ampula 'ampoule', 'ampulla', küz çokırı 'fundus of the eye', duñgiz yañagı 'epidemic parotitis' etc.). With regard to this classification, the ambiguity of terms is the matter of debate. D.S. Lotte (1961: 20) believes that any scientific and technical term should have a limited, firmly fixed content. This content should belong to the term, regardless of context. At the same time, the degree of harmfulness of ambiguous terms, according to the scientist, is different: some of them can only cause difficulties in reading literature, trouble mutual understanding, confine the possibility of experience exchange, others lead to instability of ideas and practical errors. E.N. Tolikina (1970: 57) argues that the terminological system should reproduce a system of subject-logical relations between concepts. The sign and significatum correspondence in such a system is one-to-one. R.A. Budagov (2002:33) notes that a term has one meaning, or rather, it tends to monosemy. V.V. Goncharuk and L.N. Gushchina (2009: 124) write that ambiguity nevertheless covers certain categories of words-terms, and its harm is somewhat exaggerated, since the term (although it should be understandable, regardless of context) separately, as a rule, is not used. And the context always saves it from ambiguous use;

C. by degree of motivation (fully motivated terms, partially motivated terms, unmotivated terms, pseudo-motivated terms, e.g., eng. neurectomy, cat's cry syndrome, elephant leg, café- au-lait spots; rus. pishchevod 'esophagus', bred serdtsa 'atrial fibrillation', golova meduzy 'arachnogastria', groza bulbarnaya 'a symptom complex of respiratory distress and circulatory disturbance that occurs as a complication of spinal anesthesia'; tat. gematoma 'hematoma', eremçeksıman nekroz 'caseation necrosis', cil çäçäge 'varicella' tavık küze 'hemeralopia'etc.).

D. by source language (original terms, borrowed terms, international terms, hybrid terms, e.g., eng. neck, curette, blepharism, biofeedback; rus. dal'nozorkost' 'farsightedness', skrining 'screening', bronkhit 'bronchitis', psevdoberemennost' 'pseudo-pregnancy'; tat. analıq 'uterus', gripp 'influenza', gematologiya 'haematology', khäräkät nervları 'efferent nerves' etc.);

E. by belonging to a part of speech (noun terms (and substantive phrases), verb terms, adjective terms, adverb terms, e.g., eng. epidermis, to challenge, enteropathic; in vivo; rus. angina 'angina', operirovat' 'to perform an operation', bryushnoy 'abdominal', vnutrivenno 'intravenous'; tat. migren' 'migraine', qanau 'to bleed', dävamlı 'long-term', ütä 'very' etc.).

3. Statistical classification can be considered linguistic according to the object and nonlinguistic according to the attribute, which is a statistical feature. It allows dividing the terms by frequency. Thus, as a result of the analysis of the use of terms in the text, high-frequency, mid-frequency, low-frequency terms were identified. High-frequency terms include abbreviations, abbreviated forms, textual synonyms that replace the full terms in the texts.

4. Terms are object of standardization and universalization, therefore they can be classified according to the degree of normativity. From the point of view of normative/non-normative standardized, recommended (preferable), non-standardized are distinguished. There are the unacceptable, non-recommended, and simultaneously acceptable terms among the terms rejected by the norm, in particular by the standards. The normalization of terms can be regulated not only by terminological standards, but also by other documents, depending on social needs. For example, the term hypertonia is ambiguous, but in the meaning of 
hypertension it is not recommended for use. There are another examples of terms not recommended for use are: eng. lipemia (hyperlipoproteinemia is preferable), rus. azoturia 'azoturia' (giperazoturia 'hyperazoturia' is preferable), tat. kardiopatiya 'cardiopathy' (kardiomiopatiya 'cardiomyopathy' is preferable) etc.

5. Historical classification includes terms-neologisms, obsolete-terms, terms-archaisms. Neologisms belong to developing terminological systems, e.g., eng. bigorexia, virtual autopsy, heterotopic transplantation; rus. vertebrologiya 'vertebrology', telepsikhiatriya 'telepsychiatry', ekstrakorporal'noe oplodotvorenie 'in vitro fertilization'; tat. plasmolifting 'platelet-rich plasma therapy', duñgiz grippı 'swine flu', fitokosmetologiya 'phytocosmetology' etc.; obsolete terms are associated with the concepts and realities of previous eras, e.g., eng. germ theory, sweating sickness, humorism; rus. khloroz 'chlorosis', Vrachebnaya uprava 'Doctor's Authority', dobrokachestvenniy gnoy 'laudable pus'; tat. çülmäk salu 'treatment with pot', tiryak 'drug of multi-purpose', ülänçe 'herbalist' etc.; archaisms are units of decaying terminological systems that recede into the past due to the growth of scientific knowledge and the obsolescence of certain scientific views, e.g., eng. dropsy, falling sickness, mortification; rus. nemoch' 'illness', prokaza 'leprosy', zenitsa 'pupil'; tat. zıyandaș 'epilepsy', sırkhau 'illness', qırı̆gayak 'syphilis' etc. However, since the terms remain in the language as its lexical units, they can be reborn as part of new term systems or in a new meaning during the development of the term system (Leichik et al., 1990: 22-35).

\section{Classification of Homonyms in Medical Terminology}

As mentioned above, terms according to their content structure can be classified as unambiguous and ambiguous terms. Ambiguous terms include units between which a logical-conceptual connection is formed (polysemy) and between which there is no such connection. In this research, classification of ambiguous medical terms, in the definitions of which there is no logical-conceptual connection i.e. homonymous terms are studied.

In the D.E. Rosenthal's glossary of linguistic terms homonymy in common language is defined as "sound coincidence of two or more linguistic units, different in meaning." Homonyms are subdivided into grammatical (homoforms), graphic (homographs), lexical (homonyms) and syntactic homonyms (Rozental' et al, 1985: 157). I.V. Arnold (2012: 182) defines homonymy as follows: "Two or more words that are identical in sound and spelling, but different in meaning, distribution and origin are called homonyms". R.V. Kuzmina (2007: 72-73) identifies four characteristic features of homonymy: two in terms of expression (identity of sound and/or identity of spelling), two in terms of content (difference in lexical and/or different grammatical meanings). Other features of homonymy, such as the commonness or difference in the origin of words, the completeness or incompleteness of the coincidence of paradigms, the coincidence of words in the main (dictionary) or only in indirect (nondictionary) forms, are not considered as a necessary condition for the recognition of the compared words as homonyms. They are important only for the definition of various types of homonyms heterogeneous or homogeneous, absolute or partial, dictionary or non-dictionary. In terminology, the homonym has a slightly different character. O.G. Borisova (2000: 12) identifies four main properties of homonymy in terminology - "two in terms of expression (identity of sound and spelling) and two in terms of content (difference in lexical and coincidence of grammatical meanings)".

Homonyms, in general, are classified on the basis of the following characteristics that are necessary and sufficient for identifying homonyms: identity or difference in the phonetic form of words, identity or difference in the graphic form of words, identity or difference in lexical semantics, identity or difference in general lexemic grammatical meanings. According to the signs related to the content plan, there are three substantial subtypes of homonyms: lexical and grammatical homonyms, differing in both lexical and general lexemic grammatical meanings; lexical homonyms, differing in lexical, but identical in general lexemic grammatical meanings; grammatical homonyms, differing in general lexemic grammatical meanings, but identical in lexical meanings (Kuzmina, 2007: 85-86). The 
classification of homonymous terms in the medical terminology of English, Russian and Tatar languages is further considered.

\section{Classification of Homonyms in English Medical Terminology}

In English medical terminology, the terms-homonyms can be classified into absolute, incomplete and partial homonyms, which include homophones, homographs.

Homophones are words that have the same pronunciation, different spelling, meaning and origin (Kuzmina, 2007: 91). The formation of homophones is facilitated by the features of the phonetic structure of the language (Lapochkina, 2016: 267), e.g., psychosis [sıI 'kavsis] ('major mental disorder in which the person is usually detached from reality and has impaired perceptions, thinking, responses, and interpersonal relationships' (Sell et al., 2018: 480)) - sycosis [sı' 'kavsis] (a bacterial infection of hair follicles (Bateman et al., 2005: 405)); ileum ['Iliam] (the lower part of the small intestine, between the jejunum and the caecum (Bateman et al., 2005: 191)) - ilium ['Ilizm] (the top part of each of the hip bones , which form the pelvis (Bateman et al., 2005: 191)); to heal ['hi:l] (to make someone or something get better (Bateman et al., 2005: 171)) - heel ['hi:l] (the back part of the foot (Bateman et al., 2005: 173)) etc. From these examples it can be seen that homophones can belong to different parts of speech (Arnold, 2012: 312).

Homophones appear as a result of coincidence of borrowed words with native English, random coincidence of pronunciation of words of different lexical layer, morphological changes of a word, coincidence of pronunciation of certain words in areal variants of the English language (Kuzmina, 2007: 91).

Words in which the same consonant sound is conveyed by various graphemes or their combinations in writing make up the largest group of homophones. For example, the sound [k] is indicated in writing by the following letters and letter combinations: "c", "ch", "ck", "k", "q", e.g., chord [ko:d] - cord [ko:d], sac [scek] - sack [scek] etc.

The most common oppositeness in pairs of homophones are also graphemes "c" and "s", denoting the sound [s], e.g., cell [sel] - to sell [sel], site [sait] - to cite [sait] etc. The least common are the following differences in the conveying of consonants in writing: "ps" and "s", which convey the sound [s], e.g., psychosis [sı 'kavsis] - sycosis [sı 'kavsis]; "w + consonant letter (for example wr)" - consonant letter ( $r$ ), for example wrap [ræe] wrapping (e.g., esophageal sutures with the stomach wall) - rap [ræe] etc. (Kuzmina, 2007: 172-177).

The ways of conveying the same vowels in homophones are classified into 25 different groups. In some groups there are also medical terms:

1. The first group includes a small number of words, where the grapheme "e" at the end of the word distinguishes it from another word with the same spelling, e.g., aid [eId], - aide [eId], pain [pein] - pane [pein] etc.

2. The second group also consists of a small number of words affecting the oppositeness of graphemes "i" and "y", e.g., to die [dal] - dye [dal] etc.

3. The next group includes both native English and borrowed words, in which a digraph is contrasted with a vowel in an open syllable with a final "e", e.g., "ai" - "a ... e": flair [flea] - flare [flea]; "оo" - "o ... e": poor [ps:] - pore [po:] etc.

4. One of the most frequent graphic means of distinguishing homophones is the use of different graphemes or their combinations to convey unstressed [ə], e.g., callus ['kcelos] - callous ['kcelas], naval ['neıval] - navel ['neıval], venous ['vi:nəs] - Venus ['vi:nas] etc. In addition, this group includes various methods of conveying in a writing unstressed [1] or [i] as a phoneme [1] allophone, e.g., ilium ['Ili:am] - ileum ['zli:am] etc.

5. The sound [i:] is conveyed by different digraphs "ea", “ee”, "ie", “ei”, “eo", e.g., to heal [hi:l] heel [hi:l], osteal ['nsti:al] - ostial ['nsti:al], peak [pi:k] - peek [pi:k].

6. The sound [ei] can be conveyed by the digraphs "ay", "ai", "ey", “ei”, "ee”, e.g., faint ['fernt] feint ['feint], vain [vein] - vein [vein] etc. 
7. The transposition of the vowel and consonant morphemes leads to homophony, e.g., muscle ['mısal] - mussel ['mısal] etc.

8. The sound $[\partial 0]$ is conveyed in a writing by various combinations of the graphemes "ou", "oa", "oe", "oh", "old", "olm", "olk", e.g., cold [kavld] - coaled [kəold], yolk [jovk] - yoke [jovk] etc.

9. The vowels "e", "i", "u" are used in combination with the consonant " $r$ " in the third syllable

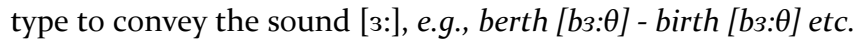

10. The diphthong [10] or [iə] can be indicated by combinations of the graphemes "eer", "ear", "ier", "eir", "ia", e.g., to sear [sı] - sere [sla], tear [tı] - tier [tı] etc.

11. Stressful [a:] is conveyed by grapheme "a" in the third syllable type and various combinations of graphemes "ear", "al", "ah", "aa", e.g., heart [ha:t] - hart [ha:t].

12. The sound [o:] is conveyed by the digraphs "au", "ou", "oa", e.g., to stanch [sto:n(t)f] - staunch [sto:n(t)f], coarse [ko:s] - course [ko:s] etc.

13. The unsounded combination of vowels "ue" in the final position of a word is found in some homophones, e.g., cue [kju:] - queue [kju:].

14. The diphthong [və] is denoted by "eu", "u”, e.g., pleural ['ploəral] - plural ['plvaral] (Kuzmina, 2007: 178-181).

According to the above mentioned examples, it is clear that homophones in some cases both belong to medical terminology, in other cases one homophone refers to either another terminological system or a general literary language.

R.V. Kuzmina (2007: 89) distinguishes the following groups of homophones: lexical and grammatical, e.g., humerus ['hju:mərəs] (n. 'the top bone in the arm, running from the shoulder to the elbow' (Bateman et al., 2005: 181)) - humorous ['hju:maras] (adj. full of humor; amusing (Hawkins et al., 2008: 227)), absolutely lexical, e.g., affusion [a'fju:zn] (n. an act of pouring a liquid on something or someone (Merriam Webster)) - effusion [a 'fju:zn] (n. escape offluid (eg, blood, lymph, serum) into a body cavity, often associated with circulatory or kidney disorders (Sell et al., 2018: 180)), absolutely grammatical, e.g., ulna ['Alna] (n. the longer and inner of the two bones in the forearm between the elbow and the wrist (Bateman et al., 2005: 433)) ulnar [' $\mathrm{A}$ lna] (adj. referring to the ulna (Bateman et al., 2005: 433)) etc. Absolutely grammatical homonyms are formed by the functional shift. Some scholars believe that converse terms cannot be homonyms. V. Abaev (1957:39) characterizes converse terms as cases of lexical-semantic polysemy and calls them "imaginary homonyms". I. S. Tyshler (1975: 10) believes that words are included in the category of homonyms only if the semantic connection between the words under consideration is broken, and lexical units correlated by functional shift are semantically related. In turn, A.I. Smirnitskiy (1956: 173) rightly emphasizes that "a picture of English homonymy, not including lexico-grammatical homonyms related to functional shift, is a highly incomplete (and therefore an incorrect) picture". The inclusion of words with functional shift relationships in homonyms is carried out on the basis of the definition of homonyms as words that differ in lexical and/or common lexemic grammatical signs of meaning. Otherwise, if words related by functional shift are excluded from homonyms, a contradiction arises in the definition of homonymy. This definition proceeds from the long-established understanding of homonyms in linguistics as language signs that have identical significative, but different significatum (Balli, 1955: 189). Grammar homonyms exist along with lexical ones, since grammatical signs of meaning, like lexical ones, are included in the concept of the significatum (Kuzmina, 2007: 87).

V. Allum (2012: 29-34) distinguishes two types of homophones: homophones and near homonyms. Near homophones are words that have different meanings and spellings and similar, but not completely identical, sounds, e.g., dysphasia [dis 'feizi:a] - dysphagia [dis 'feidzi:a], legion ['li:d3(ə)n] - lesion ['li:zən], track [trck] - tract [trcekt] etc.

Words with different meanings and pronunciation, but identical spelling are called homographs, e.g., wound ['wu:nd] (damage to external tissue which allows blood to escape (Bateman et al., 2005: 456]) - wound ['waond] (past tense of wind - go or turn something in twists, curves, or circles (Hawkins et al., 20o8: 547)); whoop ['hu:p] (cough convulsively with a crowing sound made at each inspiration (Cambridge Dictionary)) - to whoop ['wu:p] (to utter a loud cry or shout in expressing enthusiasm, 
excitement etc. (Cambridge Dictionary) etc.

There are also absolutely lexical, e.g., colon ['kavlan] (n. segment of large intestine from the cecum to the rectum (Sell et al., 2018: 128)) - colon [ $\mathrm{kb}$ 'lvn] (n. colonial farmer or plantation owner (Kuzmina, 2007: 222)) etc., lexico-grammatical, e.g., digest [dai 'dzest] (v. 'to break down food in the alimentary canal and convert it into components which are absorbed into the body' (Bateman et al., 2005: 109)) digest ['daudzest] (n. a short written report providing the most important parts of a larger piece of writing, or one containing recent news (Cambridge Dictionary)) etc., absolutely grammatical, e.g., arsenic ['a:senı] (n. metallic, highly poisonous element (Sell, 2018: 46]) - arsenic [a: 'senık] 'arsenic' (adj. of, relating to, or containing arsenic especially with a valence of five (Merriam-Webster)) etc. types among homographs,

Homophones and homographs are quite common in English, because, due to the traditionalism of spelling, the same sound can be conveyed by different graphemes and their combination, and the same grapheme or its combination can be read differently (Arnold, 2012:312). The pronunciation in the English language has changed a lot over time, which was not the case for its spelling: it has changed very little, that is why the English language has more homophones than most languages. A great deal of words has been borrowed from other languages throughout the centuries.

Absolute homonyms are words related to the same part of speech, identical in sound, spelling and grammatical forms, but having different meanings (Arnold, 2012: 267), e.g., levator - 1. muscle that lifts or raises a structure (e.g., levator scapulae, which lifts the shoulder blade); 2. surgical instrument used to lift depressed bone fragments in a fracture (Sell et al., 2018: 333); occlusion - 1. 'blockage or closing off a vessel or passageway in the body, as in a clot occluding a blood vessels'; 2 . 'manner in which the teeth in the opposing jaws meet in biting' (Sell et al., 2018: 410) etc.

There are also incomplete lexical homonyms, coinciding in most of their grammatically identical forms, e.g., os - 1. bone (in the plural form ossa); 2. mouth, or mouthlike part (in the plural form ora) (Sell et al., 2018: 419) (in this example, the plural forms of homonymic terms are not homonymous), incomplete lexical and grammatical homonyms that coincide in most of their grammatically different forms, e.g., arm - 1. n. 'the part of the body from the shoulder to the hand, formed of the upper arm, the elbow and the forearm (plural arms)' (Bateman et al, 2005: 26); 2. v. to supply someone with weapons (verb forms: arms, arming, armed) (Hawkins et al., 2008: 24) in the medical terminology of the English language. In this case, the noun in the singular form and the initial form of the verb, the noun in the plural form and the verb in the singular 3 rd person form of the Present Simple Tense coincide in pronunciation and spelling (Tyshler, 1975: 17).

A special group is made up by homonyms resulting from abbreviations. Acronyms can be considered as one of the biggest sources of homonymy in the English language. Acronyms are clippings that, as contrasted with abbreviations (that can be read, pronounced and perceived by the names of letters), are read and perceived as usual lexical formatives. They are formed in consequence of different letter combinations. Acronyms that completely match the units of a common language are called homoacronyms, e.g., pet - a tame animal kept for companionship and pleasure (Hawkins et al., 2008: 344); PET - pre-eclamptic toxemia; map - a diagram of part or all of the earth's surface or of the sky (Hawkins et al., 2008:282); MAP - mean arterial pressure; dash - a short line '-' used in writing or printing parts of a sentence (Hawkins et al., 2008: 120); DASH - dietary approaches to stop hypertension etc. (Barbasheva et al., 2015: 28-29), e.g., acronyms such as NAME (National Association of Medical Examiners), POEMS (polyneuropathy, organomegaly, endocrinopathy, monoclonal gammopathy, and skin lesions), KID (keratitis, ichthyosis, and deafness), LEOPARD ('lentigines, ECG abnormalities, ocular hypertelorism, pulmonary stenosis, abnormalities of genitalia, retardation of growth, and deafness') may cause difficulty in understanding medical texts (Al Aboud, 2015: 109).

Acronyms are divided into two groups according to the nature of their formation. The first group includes acronyms that arose during the initial abbreviation of terms and, thus, became homonyms with respect to general literary words, e.g., bat - a flying animal that looks like a mouse with wings (Hawkins et al., 2008:38]; BAT - blunt abdominal trauma etc., in this example, the coincidence of phonic and literal composition is obvious. The second group includes intentionally created acronyms. In this 
situation, the acronym includes some fragments of words of the full name and a homonym of the general literary word appears, e.g., RELY - Randomized Evaluation of Long term anticoagulant therapy etc. (Barbasheva, 2017 30).

It should also be noted that there are homonyms among the initial abbreviations. It is appropriate to speak about the homonymy of abbreviations when the concepts indicated by the abbreviations are completely not correlated by hyperonymic and hyponymic relations, e.g., FAC - 1. full blood count; 2. Federal Broadcasting Corporation; CNS - 1. central nervous system; 2. communication, navigation and surveillance; 3. carbon nanostructures etc. The number of definition variants can be two or more, e.g., $B P D$ - 1. bipolar disorder; 2. biparietal diameter; 3. bronchopulmonary dysplasia; 4. borderline personality disorder etc.

S.S. Barbasheva and others (2017: 974) emphasize that the peculiarity of polysemy and the homonymy of abbreviations is that these two phenomena can sometimes intersect with each other, e.g., the abbreviation $R B C$ is polysemic and has the following meanings: $R B C-1$. red blood cell; 2. red blood (cell) count; 3. red blood (cell) corpuscle. At the same time, the abbreviation $R B C$ has the homonym $R B C$, which stands for risk-based concentration.

\section{Classification of Homonyms in Russian Medical Terminology}

In Russian medical terminology, as O.G. Borisova (2000: 70-79) notes, cases of homophony and homography are not recorded. In addition, in her opinion, there is no point in dividing homonyms into lexical and morphological, grammatical and lexical-grammatical ones, since the studied terms belong to one part of speech, i.e. do not differ grammatically. O.G. Borisova offers a classification of homonyms according to the characteristic that appertain to all homonymous units - according to the degree of their homonymity. Depending on the degree of homonymity, homonymic terms are classified as follows: 1. Homonyms of a high degree of homonymity; 2. Homonyms of a medium degree of homonymity; 3. Homonyms of a low degree of homonymity.

Terms which definitions do not reveal common semantic components have a high degree of homonymity. This group includes terms of various origins that accidentally coincided in pronunciation and spelling, terms of general origin, which mean different, unrelated concepts, if their definitions do not have common semantic components, e.g., atopia - 1. 'atopy' [greek atopia - "something unusual, strangeness"] clinical forms of allergy caused by the development of an IgE-mediated reaction of I type hypersensitivity that occur under the natural influence of (most often entering by inhalation) allergens in individuals with a hereditary predisposition to sensibilization; 2. 'distopy' [greek a - "without, not" + topos - "place, position"] the location of the organ, tissue or individual cells in an unusual place for them, due to dysembryogenesis, trauma or surgery (Unabrid. encycl. dict. of medical terms, 2012: 163); razreshenie - 1. 'resolution' - in optics - the ability to distinguish details optically; 2. 'solution' - in medicine - the critical end of the disease (Unabrid. encycl. dict. of medical terms, 2012:1507).

This group includes one-component terms, which allowed the author to assume that the degree of homonymity of the terms depends on the number of components in it: the less components are in term, the higher the degree of homonymity.

The medium degree of homonymity of homonymous terms implies the absence of a common semantic component in their definitions in the first stage of component analysis, but its identification in subsequent stages, e.g., amputatsiya - 1. 'amputation', 'ablation' cutting off or tearing off a limb, its peripheral part or the peripheral part of an organ (uterus, mammary gland) ); 2. 'amputation' direct separation from the body and elimination of the appendage or pathological growth, such as a polyp (Unabrid. encycl. dict. of medical terms, 2012: 65), (cutting of means much about the same as separation, that's why they are considered as a common semantic component found in the second stage of the component analysis), etc.

The terms of a low degree of homonymity consist of the largest group of homonymic terms in Russian medical terminology. This group includes terminological units denoting different, unrelated concepts, in the definitions of which there is a general seme of a non-special nature, e.g., geteroplazia 
- 1. 'heteroplasia' the development of pathological cytological and histological elements in an organ or tissue; 2. 'heteroplasia', 'malignancy' replacement of normal tissue or part of it with tissue of malignant growth; (tissue is a common semantic component in the term definitions) (Unabrid. encycl. dict. of medical terms, 2012: 416); terapiya biologicheskaya - 1. 'biological therapy' treatment of bodily and physical disorders; terapiya biologicheskaya - 2. 'biological therapy' treatment with using biological drugs, etc. (Unabrid. encycl. dict. of medical terms, 2012: 1910).

In Russian, homonymous abbreviations are also wide spread, e.g., $P D$ - 1. dose limit; 2. action potential (Unabrid. encycl.dict.of medical terms, 2012: 1283); AKDS - 1. 'DTP' adsorbed pertussisdiphtheria-tetanus vaccine; 2. oxygen-producing mobile station (Unabrid. encycl.dict.of medical terms, 2012: 31); VPG - 1. 'HSV' herpes simplex virus; 2. military field hospital etc. (Unabrid. encycl.dict.of medical terms, 2012: 357). Acronyms, on the contrary, are extremely rare in the medical terminology of the Russian language, e.g., voz 'cart' - a cart loaded with a luggage (Ushakov, 2014: 67) VOZ 'WHO' - the World Health Organization.

\section{Classification of Homonyms in Tatar Medical Terminology}

In medical terminology of the Tatar language, two groups of homonyms can be distinguished: absolute and incomplete homonyms. The group of absolute homonyms includes lexical homonyms that coincide in all their grammatically identical forms. Therefore, these are words that belong to the same part of speech (Suyunov, 2004: 94), e.g., qabaq - 1. 'pumpkin' a genus of big annual, usually lianoid, plants of the pumpkin family (Cucucrbitaceae) with broad palmate-laciniate leaves and a large fleshy fruit pumpkin; 2. 'eyelid' movable fold of skin over the eye (Explan. dict. of the Tatar lang., 2017: 13), yatqliq 1. 'deposit (of mineral resources)' natural accumulation of a mineral substance on the surface or in the Earth interior; 2. 'placenta' afterbirth, secundines (Miftakhov, 2012); qızılça - 1. 'rubella' 'contagious viral disease characterized by fever, mild symptoms of upper respiratory infection, and a diffuse, fine, red rush'; 2. 'cotoneaster' deciduous or evergreen shrubs with medium-sized, simple, alternate, plain, oviform, dark green in the summer, reddening in the fall (most often shiny) leaves, flowers are white or pink, small, in corymbs, racemes or solitary (Explan. dict. of the Tatar lang., 2017: 664).

Incomplete homonyms include homoforms, homophones and homographs. In medical terminology of the Tatar language, homophones are not found, and there are only individual cases of homographs. The words кабак [къа ба къ] (qabaq 'eyelid') and кабак [кабак] (kabak 'rumshop' - а pub that sells cheap strong liquor (Explan. dict.of the Tatar lang.,2017: 13)), in term, are homographs, the sound [ $k z]$ ' $q$ ' is harder than $[\kappa]$ ' $k$ ', but such cases are rare in the medical terminology of Tatar language. Homoforms are words in which the phonetic structure of some forms coincides, while others diverge. Accordingly, one of such units is a homonym in relation to a certain form or certain forms of another unit (Suyunov, 2004: 96). In medical terminology of the Tatar language, homoforms, in most cases, are found among words belonging to different parts of speech, e.g., avir - 1. (adj.) 'heavy' having the heaviness, a lot of weight (e.g. in comparative degree this word has form aviruraq); 2. (adj.) 'complicated' difficult to carry out, to understand (e.g. in comparative degree this word has form aviruraq); 3. (n.) 'pregnancy' childbearing (in accusative case avırnı) (Explan. dict.of the Tatar lang., 2015: 43-44]; therefore, in form of different grammatical categories their phonetic structures do not coincide: avırıraq- avirnı; agu - 1. (n.) 'poison' a substance that leads in certain doses, in small relative to body weight, to abnormality of the body: poisoning, disease, other painful conditions and deaths; 2. (v.) 'to leak', 'to run' to pour, move, densely filling the empty space under the influence of external force (Explan. dict.of the Tatar lang., 2015: 58); ciränçä - 1. (adj.) 'reddish' in some degree red; 2. (n.) 'urticaria' a disease in which itchy blisters, similar to sting, quickly appearing and disappearing on the skin. (Explan. dict.of the Tatar lang., 2016: 355).

When studying the phenomenon of homonymy, special attention is paid to functional shift, in connection with its wide distribution in the lexical and grammatical systems of the Tatar language. As A.A. Yuldashev noted in the 70 of of the last century, functional shift is a characteristic phenomenon for Turkic languages (Semenova, 2012: 9). Functional shift is the formation of a new word by shifting of 
the stem to another part of speech. It is a lexico-grammatical way of forming new words. This way of enriching vocabulary is used both in English and in the Tatar languages (Khisamova et al., 2019: 80). As A.I. Smirnitskiy (1956: 173) noted, homonyms associated with functional shift are a very special group of cases of partial complex lexico-grammatical homonymy. The picture of homonymy in the English language will be incomplete without this group of homonyms, the same conclusion can be made for the Tatar language, taking into account the above comments on the functional shift in it, e.g., avıru - 1 . (v.) 'to be sick' to get sick, to contract an illness, become unwell; 2. (n.) 'disease' health disorder of a living organism and its disfunction; 3. (n.) 'sick', 'ill' person, having a broken health, affected by any disease etc. (Explan. dict. of the Tatar lang., 2015: 48).

Converse terms have an identical stem, but vary in form. They are formed through a paradigm shift and differ from each other only in a paradigm. The presence of forms of different parts of speech in words having the identical sound, sometimes possessing semantic independence, is obligatory for functional shift (Beshirov, 2002: 71-72).

Homonyms-converse terms can be classified in the Tatar language according to the model that B.Sh. Beshirov distinguishes in the Kumyk language.

Functional shift relations, where the differences of converse terms are wholly reducible to syntax, are functionally determined and equated with syntactic derivation - syntactic derivatives are functional grammatical homonyms. The scope of grammatical homonymy in such cases is limited by syntactic movement (transposition), but not by transformation of lexical units. Syntactic derivation is the most common type of homonymous functional shift relations, as a result of such derivation, grammatical homonymy of cognate words originates, e.g., aqsaq - 1. (adj.) 'limped' having a shortened, crippled, or sore leg, unable to walk straight; 2. (n.) 'lame man' the one, who is limping (Explan. dict.of the Tatar lang., 2015: 105). The noun aqsaq 'lame man' is used in a predicative construction, e.g., aqsaq yöri almiy 'lame man cannot walk'. The adjective aqsaq 'limped' is used in the attribute structure, e.g., aksak keshe 'limped man'.

The second type of functional shift relations is the result of lexical derivation. It implies some changes in the semantics of the derivative compared to the semantics of the forming words. Taking into account the fact that converse terms belong to different parts of speech, such homonymous relations between converse terms are called lexical-grammatical relations, e.g., ğarip - 1. (n.) 'disabled' disabled person; 2. (adj.) 'with a deficiency' defective, imperfect (Explan. dict.of the Tatar lang., 2016: 48). The grammatical homonymy 'noun - adjective' together with lexical derivation establishes the lexicogrammatical homonymy between converse terms. The lexical transformation 'subject - its distinguishing feature' differentiates the co-occurrence of converse terms. A derived adjective highlights an important, appraisive definition of a feature. The word denoting a sign is used more freely, e.g., ğarip yullar 'broken roads' etc. The grammatical homonymy 'adjective - noun' is resonated with the lexical transformation 'sign - carrier', e.g., aq - 1. (adj.) 'white' of the color of snow, milk, chalk; 2. (n.) 'leucoma' a whitish spot on the cornea of the eye after inflammation of it or damage to the eye (Explan. dict.of the Tatar lang., 2015: 97). The lexical derivation changes the context of the lexical co-occurrence of converse terms, e.g., aq külmäk 'white dress' and küzdäge aqnı dävalau 'the treatment of leucoma'. The grammatical and lexical characteristics of converse terms establish homonymous relations between them.

The next type of functional shift relations involves semantic and grammatical transformations. Due to them, a boundary is established between the area of use of the forming and derived words. In this case, a gap occurs between lexical units, since semantic transformations break the identity of the word. Grammatical transformations confirm the individuality, independence of the derived word. Words related by functional shift are homonymous semantic derivatives, e.g., qatu - 1. (v.) 'to solid', 'to dry up' to become solid, dry, losing moisture; 2. (n.) transient abdominal pain associated with exercise (Explan. dict. of the Tatar lang., 2017: 173-174); e.g. ipi qatqan 'bread has dried up' and qatu çıtı 'transient abdominal pain has appeared' (Beshirov, 2002: 73-78).

Homonyms-abbreviations of original Tatar language - a rare phenomenon in the Tatar medical terminology. At the same time, homonyms-abbreviations borrowed from Russian without translation 
into Tatar are widespread. In the Tatar language, among the terms considered during the study, a term that has a homoacronym was discovered: rak 'cancer' - 1. 'cancer'; 2. 'malignant tumor' life-threatening type of tumor based on a malignant neoplasm, which consists of malignant cells. (Rus.-Tat. Med. Explan. Dict., 2003: 398); RAK - Republican Food Corporation.

\section{Homonymity of Eponymous Terms}

Medical terminology contains a huge number of eponymous terms. Eponyms, like other terms, are characterized by lexico-semantic phenomena, including homonymy. Among eponymous terms, homonyms are very common, and they can cause difficulties.

O.G. Borisova (2000:35) emphasizes that the specificity of eponymous terms is that they combine the properties of both terms and onomastic vocabulary. It is this circumstance that contributes to the consideration of eponymous terms as an independent group, in determining the nature of semantic relationships between eponyms, characterized as multivalent.

According to the author, ambiguous eponyms, depending on the ownership of a proper name, which is the basis of the eponymous term, to one or different personalities, can be classified into two groups. The first group includes genetically homogeneous (of the same name) eponymous terms, i.e. a term that is associated with the same person has several meanings that are not related to each other, e.g., Barre's syndrome/sindrom Barre/Barre sindromı in honor of the French neuropathologist J.A. Barre, 1880-1967 - 1. burning and constricting pains in the abdomen and lower limbs, sensation of inflow of hot or icy water to the limbs; observed during the spinal cord compression, syn. Barre painful syndrome; 2. combination of manner of walking disorder, instability in the Romberg position and nystagmus towards the pathological focus, observed with damage to one hemisphere of the cerebellum, syn. Barre disharmonious syndrome (Petrov et al., 2005: 42).

The second group consists of genetically heterogeneous or the same name eponymous terms, i.e. terminological units associated with different persons whose surnames/names coincided randomly, e.g., Wood's syndrome/sindrom Vuda/Vud sindromı in honor of 1 . English cardiologist P.H. Wood, 1907-1962 - a set of electrocardiographic changes; $T V_{2}-V_{3}$ - wave inversion, deep wave $S_{1}$ and Q111; observed with massive embolism in the pulmonary trunk system; 2. American ophthalmologist N. Wood - symptom complex of deep anesthesia; relaxation of the orbicular muscle of the eye, divergent strabismus, fixation of eyeballs in the same position (Petrov et al., 2005:378) etc.

It is necessary to note the fact that some proper names that make up eponymous terms can differ in sound and spelling in English and Russian, and therefore in Tatar languages. For example, Behr's sign and Ber's sign from English have the same sound and spelling in Tatar and Russian, in turn, in English these two terms are homophones: Behr's sign/sindrom Bera/Ber sindromı - a combination of homonymous hemianopsia with mydriasis and palpebral fissure distension on the side of hemianopsia; observed with disorder of the visual tract; Ber's sign/sindrom Bera/Ber sindromı - keratinization and thickening of the epidermis in the elbows and knees with hypotheriosis, syn. symptom of "dirty elbows" (Petrov et al., 2005: 48, 50).

An analysis of the definitions of the same name term shows that the names refer to different, unrelated concepts, i.e. differ in denotation.

\section{Types of Homonymy Medical Terminology}

In medical terminology, three large groups of homonyms are distinguished.

1. Intra-terminosystem (intra-scientific) homonymy - homonymy between units of one terminological system. This type of homonyms is quite rare, because homonymy within the terminological system of one science is regarded as a negative phenomenon, especially, when it comes to homonyms-abbreviations. The medical term system, in turn, consists of many subsystems. Therefore, terminological homonymy can be considered as an intra-systemic phenomenon. The analysis of medical terms allows us to note that the same medical term can 
mean completely different concepts in its various subsystems, e.g., eng. isolation - in surgery - 1. separation of a structure from surrounding structures; 2. in epidemiology - separation of a patient suffering from a contagious disease, from contact with others (Sell et al, 2018: 307); rus. aktivatsiya - 1. in diagnostics - 'arousal' the phenomenon of suppression or disappearance of EEG rhythms by a physiological or other stimulus with the appearance of low-amplitude highfrequency activity; 2. in oncology - 'activation' the first stage of tumor induction by a carcinogen; minor damage to cells under the influence of a carcinogenic agent, in which these cells are prone to form a tumor with prolonged subsequent action of the promoter (promotion) (Unabrid. encycl. dict. of medical terms, 2012: 36); tat implantatsiya - 1. in embryology 'implantation' embryo insertion in the uterine mucosa; 2. plastic surgery - 'implantation' implantation of various materials in tissue (Rus.-Tat. Med. Explan. Dict., 2003: 177-178).

2. Inter-terminosystem (inter-scientific) homonymy between units of different terminological systems. Inter-scientific terminological homonyms have two obligatory features: 1 . the terms have completely different definitions; 2 . these terms are used in different terminologies (Danilenko, 1977: 71). In most cases, there is no semantic derivation relationship between the meanings of terms. But in some cases, one can retrace the reason for the origin of a new term in medicine. (Grosheva, 2015: 982). In medical terminology, these are terms that coincide in form and function in non-medical and non-conterminous with the medical terminological systems. The discrepancies between the terms of different sciences are significant, so it is necessary to keep in mind only their general internal form, on the basis of which different meanings have developed in different terminological systems, but not the relationship between the concepts they designate (Borisova, 2000: 91), e.g., eng. axis - 1. in politics - an agreement between governments or politicians to work together to achieve a particular aim (Cambridge Dictionary); 2. in medicine - the second cervical vertebra: the second bone of the vertebral column, located in the neck region (Sell et al., 2018: 6o); rus. regressiya - 1. in mathematics - 'regression' the statistical dependence of the conditional mathematical expectation of a random variable on a random vector (Kaazik, 2007: 244); in medicine 'regression' a decrease in the clinical picture (Unabrid. encycl. dict. of medical terms, 2012:1541); tat. appendiks - 1. in techniques - 'appendix' a short hose at the bottom of the air-balloon, aerostat, airship, which serves to fill the shell with gas and to release its surplus during the flight; 2. in medicine - 'appendix' vermiform appendage of cecum etc. (Explan. dict. of the Tatar lang., 2015: 194).

3. Intersystem (macrosystem) homonymy - homonymy between terminological units and words of a general literary language. Such homonymous relations originate from the terminologization of commonly used words, i.e. transition of a common word into a term. After terminologization, as a rule, the subsequent development of the term occurs, among which the introduction of new meanings, polysemantization, homonymization and other cases of the asymmetry of the linguistic sign, e.g., eng. canal-1. 'a long, thin stretch of water that is artificially made either for boats to travel along or for taking water from one area to another' (Cambridge Dictionary); 2. relatively narrow tube, generally for conducting materials other than blood or lymph (Sell et al., 2108: 95); rus. yachmen' - 1. 'barley' cereal, usually spring, which grains are used for the production of grits, flour, beer, coffee substitutes and fodder (Ushakov, 2014: 799); 2. 'sty' purulent inflammation of the glands of the eyelid (Unabrid. encycl. dict. of medical terms, 2012: 2242); tat. çükeç - 1. 'hammer' driving bench-work or carpenter tools, heavy metallic ingots on the handle; 2. 'malleus' auditory ossicle of the middle ear. (Miftakhov, 2012) etc.

O.G. Borisova (2000: 109-112) claims that there is still no consensus that the term is a homonym for the common word from which it is derived, or it is one of the meanings of a multivalent term. In dictionaries, they can be represented in different ways. Some scientists, e.g., D.S. Lotte, S.V. GrinevGrinevich, Yu.S. Stepanov consider the relationship of commonly used words and terms as homonyms. In this study, such relationships are also considered as homonymous ones. 


\section{Homonymity of Greek-Latin Terminological Elements}

Greek-Latin terms form the core of medical terminology. Despite the fact that both Greek and Latin are extinct languages, their word-formation resources are used in modern medical science. Some Greek-Latin terminological elements have several meanings, and this fact allows talking about the homonymity of terminological elements in medical terminology, e.g., the prefix dia/di (for example, as in diataxia) - 1. movement through, from beginning to end in space or in time; 2. full completion of the action; 3. disjointing, separation; 4. intermediate position between something (Unabrid. encycl. dict. of medical terms, 2012, p. 539); in complex words vaz (o) (for example, as in vasoligature) - 1. related to blood vessels; 2. related to the vas deferens, etc. (Unabrid. encycl. dict. of medical terms, 2012: 277).

\section{Relation of Homonymy and Partial Synonymy}

The phenomenon of homonymy in medical terminology intersects with partial synonymy. In addition, in some cases, synonyms for each of the meanings are a way that helps correctly understand and distinguish terms. Homonymous terms, as a rule, have synonyms through one semantic line, e.g., eng. auricle - 1. outer visible part of the ear (syn. pinna); 2. a small conical pouch projecting from the upper anterior portion of each atrium of the heart (Sell et al., 2018: 56); rus. perevyazka - 1. 'bandage' treatment and diagnostic procedure, including examination and toilet of the wound, local treatment procedures and dressing application; 2. 'ligation' closing the lumen of the organ of a tubular shape by tightening the ligature circled around it (syn. ligirovanie) (Unabrid. encycl. dict. of medical terms, 2012: 1287); tat. anesteziya - 1. 'anesthesia' nonsensibility (syn. sizmäüçänlek); 2. 'anesthesia' common name for anesthetization ways (syn. avırtusızlandıru) 'anesthesia' (Rus.-Tat. Med. Explan. Dict., 2003: 34). In these examples, it can be seen that the term auricle has a synonym through the first semantic line (auricle - pinna), the ligation has a synonym through the second semantic line (perevyazka ligirovanie), anesthesia has synonyms for both semantic lines (anesteziya ${ }^{1}$ - sizmäüçänlek, anesteziya ${ }^{2}$ - avırtusızlandıru).

\section{Methodology}

The terms for research were taken from Dictionary of English medical terms by R. Sell et al., Unabridged Encyclopedical Dictionary of Medical Terms under the editorship of E.G. Ulumbekov (Russian language), Explanatory Dictionary of the English Language by Hawkins et al., Medical Russian-Tatar Explanatory Dictionary under the editorship of M.M. Gimadeev, Explanatory Dctionary of the Tatar language: Volume I, II,III, Explanatory dictionary of the Tatar language by Z. Miftakhov, English-Russian Medical Dictionary of Eponymous Terms by V.I. Petrov, Dictionary of Lexical and Lexical-Grammatical Homonyms of Modern English by I.S. Tyshler, Explanatory Dictionary of the Modern Russian language by D.N. Ushakov. Our study is based on comparable interpretations: homonyms and their classification groups in medical terminology are studied in each individual language, and the results are compared, which makes it possible to identify common and distinctive types of homonyms in the medical terminology of three languages.

\section{Results}

Thus, the medical term system is a complex and has many subsystems. Medical terms are classified on various characteristics. One of the main classification groups in medical terminology is linguistic, which includes division by content structure, that includes ambiguous terms in the definitions of which there is no logical-conceptual connection, i.e. homonyms.

Homonymy in medical terminology, as well as in the general literary language, is a widespread phenomenon. It affects not only terms-words, terms-phrases, eponymous terms, but also abbreviations, acronyms and term elements. 
R.V. Kuzmina's definition of homonyms is applicable to the homonymy of the medical terminology of the English and Tatar languages, since conversion homonyms are considered in these languages, and the difference in grammatical meanings is mentioned in its definition. O.G. Borisova examines homonymy in the medical terminology of the Russian language and classifies homonyms only according to the degree of homonymity.

Homonymous medical terms are divided into three main groups: intra-terminological, interterminological, intersystem homonymy in Russian, English and Tatar languages. Intraterminological homonymy - homonymy of terms within one terminological system. This type of homonymy is considered undesirable, but in medical terminology it is very common due to the existence of subsystems. The terms homonyms from different subsystems of medicine are considered as of internal terminological system in medical terminology. Inter-term homonymy - homonymy of terms of different terminological systems. Intersystem homonymy occurs during terminologisation, metaphorization of commonly used words with the subsequent development of the term (the introduction of new meanings, polysemantization, homonymization, etc.).

In the medical terminology of the English language, the following groups of homonyms are found: absolute, incomplete, partial (homophones, homographs) homonyms. Incomplete homonyms are divided into lexical and lexical and grammatical, and partial homonyms are divided into lexical, lexical and grammatical, grammatical (homonyms-converse terms). Homophones, in turn, are classified into homophones and near homophones. The prevalence of homophones and homographs is closely related to the phonetic features of the language (the same grapheme or digraph can be pronounced differently, the same sound can be transmitted by different graphemes or digraphs). Unlike the medical terminology of the Russian and Tatar languages, homonymy of acronyms is widespread in English.

Homonyms are classified into homonyms of a high degree of homonymity, homonyms of a medium degree of homonymity, homonyms of a low degree of homonymity in Russian medical terminology. The group of terms of a high degree of homonymity includes terms in the definitions of which no common semes are found, homonyms of the middle degree of homonymy include terms that do not have common semes in the definitions at the first stage of component analysis, but have them at the subsequent stages of it. Terms of low degree of homonymity have common non-special semes at the first stage of analysis.

In medical terminology of the Tatar language, two groups of homonyms are distinguished: absolute and incomplete. Incomplete homonyms include homoforms that belong to different parts of speech and homographs. Homographs are rare phenomenon in the medical terminology. Absolute homonyms coincide in sound and spelling, but have different meanings. The same group also includes borrowed homonyms. Separately, as a special group of homonyms, homonyms-converse terms are considered. There are three types of functional shift relations in the Tatar language: syntactic, lexical and semantic, the most common of which is syntactic relation.

Homonymy is also found among eponymous terms. In most cases, such terms coincide in three languages, in individual cases, such terms in English can only be partial homonyms, while in Russian and Tatar languages they are absolute homonyms.

The phenomenon of homonymy affects the Greek-Latin terminological elements, which are international.

\section{Conclusion}

Thus, in the medical terminology of each of the languages under consideration, the phenomenon of homonymy has its own characteristics.

Absolute homonyms are found in all three languages. In Russian, absolute homonyms are considered in terms of the degree of homonymity, and this is the only classification of homonyms that is suitable for the medical terminology of the Russian language.

In the medical terminology of the English language, lexical, lexical and grammatical and grammatical homophones, homographs are widespread. 
Incomplete lexical and grammatical homonyms are found in English and Tatar languages, and incomplete lexical homonyms heavily are characteristic only for the medical terminology of the English language. The pronunciation in the English language has changed a lot over time, which was not the case for its spelling: it has changed very little, that is why the English language has more homophones than most languages. A great deal of words has been borrowed from other languages throughout the centuries

In the English and Tatar languages, homonymy arises as a result of the functional shift. In the Tatar language, three types of functional shift relationships are considered: syntactic, lexical, and semantic.

\section{References}

Abaev, V.I. 1957. O podache omonimov v slovare. (About Presentation of Homonyms in the Dictionary). In: Voprosy Yazykoznaniya, n. 3, pp. 31-43.

Al Aboud, K. 2015. Homonyms in Medicine: A Perspective. In: Our Dermatol Online, n. 1, pp. 109-110. DOI: 10.7241/ourd.20151.30. ISSN 2081-9390.

Allum, V. 2012. English for Medical Purposes: Spelling and Vocabulary. Raleigh: Lulu Press. ISBN 978-1-4717-6562-9

Arnol'd, I.V. 2012. Leksikologiya sovremennogo angliyskogo yazyka. (Lexicology of Modern English). 2nd ed. Moscow: Flinta: Nauka. ISBN 978-5-9765-1041-8 (Flinta). ISBN 978-5-02-037352-5 (Nauka)

Averbukh, K.YA. 2005. Obshchaya teoriya termina: kompleksno-variologicheskiy podkhod. (The General Theory of the Term: A Complex-Variological Approach): Doctoral Thesis: 10.02.19. Ivanovo.

Bally, CH. 1955. Obshchaya lingvistika I voprosy frantsuzskogo yazyka. (General Linguistics and Problems of the French language). Moscow: Izdatel'stvo inostrannoy literatury.

Barbasheva, S.S. \& Rozhkova, T.V. 2017. Meditsinskie akronimy i omokronimy: klassifikatsiya, problemy upotrebleniya i perevoda. (Medical Acronyms and Homoacronyms: Classification, Problems of Use and Translation). In: Vestnik TGPU (TSPU Bulletin, n. 3 (180), pp. 28-32. ISSN 1609-624X.

Barbasheva, S.S. \& Rozhkova, T.V. 2015. Polisemiya i omonimiya meditsinskikh abbreviator. (Polysemy and Homonymy of Medical Abbreviations). In: Meditsinskoe terminovedenie, vol.17, n. 5-3, pp. 972-975 ISSN 19905378

Bateman, H., Hillmore, R., Jackson, D, Lusznat, S., Mcadam, K. \& Regan, CH. 2005 Dictionary of Medical Terms. 4th ed. London: A \& C Black Publishers Ltd. eISBN-13: 978-1-4081-0209-1

Beshirov, B.SH. 2002. Omonimiya v sovremennom kumykskom yazyke. (Homonymy in the Modern Kumyk Language): Candidate's Thesis: 10.02.02. Makhachkala.

Bol'shoy entsiklopedicheskiy slovar' meditsinskikh terminov. (Unabridged Encyclopedical Dictionary of Medical Terms). 2012. Ulumbekov E.G.(eds). Moscow: GEOTAR-Media. ISBN 978-5-9704-2010-2

Borisova, O.G. 200o. Omonimiya terminov meditsinskikh nauk. (Homonymy of Terms of Medical Sciences): Candidate's Thesis: 10.02.01. Krasnodar.

Budagov, R.A. 2002. Vvedenie v nauku o yazyke. (Introduction to the Science of Language). 3 ed. Moscow: Dobrosvet-200o. ISBN 5-94119-015-8

Cambridge Dictionary. 2020. [Online] Available: https://dictionary.cambridge.org/dictionary/english/ (January 04, 2020)

Danilenko, V.P. 1977. Russkaya terminologiya: opyt lingvisticheskogo opisaniya. (Russian Terminology: the Experience of Linguistic Description). Moscow: Nauka.

Goncharuk, V.V. \& Gushchina, L.N. 2009. Puti razvitiya polisemii i eyo rol' v meditsinskoy terminologii. (Ways of Development of Polysemy and Its Role in Medical Terminology). In: Zhurnal GrGMU, n. 3(27). pp. 123-125. ISSN 2221-8785, eISSN 2413-0109.

Grinev-Grinevich, S.V. 2008. Terminologiya (Terminology). $9^{\text {th }}$ ed. Moscow: Izdatel'skiy Tsentr "Academy". ISBN 978-5-7695-4951-9

Grosheva, A.A. 2015. Terminologicheskaya omonimiya v yazyke meditsiny. (Terminological Homonymy in the Language of Medicine). In: Izvestiya Samarskogo nauchnogo tsentra Rossiyskoy akademii nauk, vol. 17, n. 5, pp. 981-983. ISSN 1990-5378.

Hawkins, J., Delahanti, E. \& Macdonald, F. 2008. Explanatory Dictionary of the English Language. Moscow: Astrel'. ISBN 978-5-271-20338-1

Kalinin, A.V. 1978. Leksika russkogo yazyka. (Vocabulary of the Russian Language). 3 ed. Moscow: Izdatel'stvo Moskovskogo universiteta. 
Kaazik, YU.A. 2007. Matematicheskiy slovar. (Mathematical Dictionary). Moscow: Fizmatlit. ISBN 978-5-9221-o847-8

Khisamova, V.N. \& Ibatulina, L.M. 2019. Slovoslozhenie, konversiya i abbreviatsiya kak sposoby obrazovaniya khimicheskoy terminologii v angliyskom i tatarskom yazykakh. (Compounding, Conversion and Abbreviation as Ways of Forming Chemical Terminology in English and Tatar Languages). In: Kazanskiy lingvisticheskiy zhurnal, n. 2(1), pp. 75-85. ISSN 2658-3321

Kondakov, N.I. 1975. Logicheskiy slovar'-spravochnik. (Logical Reference Dictionary). 2nd ed. Moscow: Nauka.

Kuzmina, R.V. 2007. Foneticheskaya variativnost' i variantnost' v angliyskom yazyke i printsipy ikh otrazheniya v sovremennykh orfoepicheskikh slovaryakh (fonetiko-leksikograficheskoe issledovanie na material fenomena omonimii). (Phonetic Variability and Variation in the English Language and the Principles of Their Reflection in Modern Orthoepic Dictionaries (Phonetic-Lexicographic Research on the Material of the Homonymy Phenomenon): Candidate's Thesis: 10.02.19. St. Petersburg.

Lapochkina, A.S. 2016. Yavlenie omonimii v angliyskoy terminologii khimicheskoy tekhnologii. (The Phenomenon of Homonymy in the English Terminology of Chemical Technology). In: Yazyk nauki i tekhniki v sovremennom mire: materialy V mezhdunarodnoy nauchno-prakticheskoy konferentsii. Omsk: Omsk State Technical University, pp. 120-124. ISBN 978-5-8149-2213-7

Leichik, V.M. \& Shelov, D.S. 1990. Lingvisticheskie problemy terminologii i nauchno-tekhnicheskiy perevod. Chast' 2. (Linguistic Problems of Terminology and Scientific and Technical Translation. Part 2). Moscow: VTsP.

Lotte, D.S. 1961. Osnovy postroeniya nauchno-tekhnicheskoy terminologii. (Fundamentals of Building Scientific and Technological Terminology). Moscow: Academiya Nauk SSSR.

Meditsinskiy russko-tatarskiy tolkovyy slovar'. (Russian-Tatar Medical Explanatory Dictionary). 2003. Gimadeev M.M. (eds.). Kazan: Magarif. ISBN 5-7761-0819-5

Merriam-Webster. 2020. [Online] Available: https://www.merriam-webster.com/dictionary (January, 05 2020)

Mishlanova, S.L. \& Filippova, A.A. 2010. Vnutriotraslevaya polosemiya v metodicheskom diskurse: monografiya. (IntraSectoral Polysemy in A Methodical Discourse: A Monograph). Perm: Permskiy gosudarstvennyy universitet.

Miftakhov, Z. 2012. Tatar teleneñ añlatmalı süzlege. (Explanatory Dictionary of The Tatar language). Zainsk: Şäkhsi kitap näşriyatı. Aplication for the site. [Online] Available https://watan.su/ (January, 10 2020)

Petrov, V.I. \& Perepelkin, A.I. 2005. Anglo-russkiy meditsinskiy slovar' eponimicheskikh terminov. (English-Russian Medical Dictionary of Eponymous Terms). Moscow: Meditsina. ISBN 5-225-03622-8

Rozental', D.E. \& Telenkova, M.A. 1985. Slovar-spravochnik lingvisticheskikh terminov. (Glossary of Linguistic Terms). $3^{\text {rd }}$ edition. Moscow: Prosveshchenie,

Sell, R., Rothenberg Mikel A. \& Chapman Charles, F. 2018. Dictionary of Medical Terms. 7th edition. New York: Barron. ISBN 978-1-4380-1037-3

Semenova, E.V. 2012. Aktual'nye zadachi issledovaniya voprosov omonimii v sovremennom yakutskom yazyke. (Crucial Tasks of The Study Of Homonymy in The Modern Yakut Language). In: Politematicheskiy setevoy elektronnyy nauchnyy zhurnal KubGAU, n. 83 (o9), pp. 1-11. ISSN 1990-4665 (Print), ISSN 1990-4665 (Online).

Smirnitskiy, A.I. 1998. Leksikologia angliyskogo yazyka. (Lexicology of the English Language). Moscow: MGU. ISBN 5-89042-043-7

Stepanov, YU.S. 1975. Osnovy obshchego yazykoznaniya. (Fundamentals of General Linguistics): 2nd ed. Moscow: Prosveshcheniye. ISBN 6o6o2-292-10-74

Suyunov, Z.S. 2004. Omonimiya nogaiskogo yazyka. (Homonymy of the Nogai language): Candidate's Thesis: 10.02.02. Makhachkala.

Tatar teleneñ añlatmali süzlegle: I Tom. (Explanatory Dictionary of the Tatar Language: Volume I). 2015. Kazan: TÄhSI. ISBN 978-5-93091-189-3

Tatar teleneñ añlatmali süzlegle: II Tom. (Explanatory Dictionary of the Tatar Language: Volume II). 2016. Kazan: TÄhSI. ISBN 978-5-93091-205-o

Tatar teleneñ añlatmali süzlegle: III Tom. (Explanatory Dictionary of the Tatar Language: Volume III). 2017. Kazan: TÄhSI. ISBN 978-5-93091-225-8

Tolikina, E.N. 1970. Nekotorye lingvisticheskie problemy izucheniya termina.(Some linguistic problems of studying the term). In: Lingvisticheskie problemy nauchno-tekhnicheskoy terminologii, pp. 53-67.

Tyshler, I.S. 1975. Slovar' leksicheskikh i leksiko-grammaticheskikh omonimov sovremennogo angliyskogo yazyka. (Dictionary of Lexical and Lexical-Grammatical Homonyms of Modern English). Saratov: Izdatel'stvo Saratovskogo Universiteta. ISBN 7-1-4-247-71

Ushakov, D.N. 2014. Tolkovyy slovar' sovremennogo russkogo yazyka (Explanatory Dictionary of the Modern Russian Language). Moscow: Adelant. ISBN 978-5-93642-345-1 